\title{
BMJ Open Fatty liver disease and the risk of erosive oesophagitis in the Korean population: a cross-sectional study
}

\author{
Ja Sung Choi, ${ }^{1}$ Hee Man Kim, ${ }^{2,3}$ Yun-Jung Yang, ${ }^{4}$ Sangheun Lee, ${ }^{1}$ \\ Seok-Hoo Jeong, ${ }^{1}$ Ki Jun Han $^{1}$
}

To cite: Choi JS, Kim HM, Yang Y-J, et al. Fatty liver disease and the risk of erosive oesophagitis in the Korean population: a crosssectional study. BMJ Open 2019;9:e023585. doi:10.1136/ bmjopen-2018-023585

- Prepublication history for this paper is available online. To view these files, please visit the journal online (http://dx.doi. org/10.1136/bmjopen-2018023585).

Received 20 April 2018 Revised 9 0ctober 2018 Accepted 10 October 2018

Check for updates

(c) Author(s) (or their employer(s)) 2019. Re-use permitted under CC BY-NC. No commercial re-use. See rights and permissions. Published by BMJ.

${ }^{1}$ Division of Gastroenterology, Department of Internal Medicine, Catholic Kwandong University International St. Mary's Hospital, Incheon, Korea

${ }^{2}$ Division of Gastroenterology and Hepatology, Department of Internal Medicine, Yonsei University Wonju College of Medicine, Wonju, Korea ${ }^{3}$ Department of Physiology and Cell Biology, University of Nevada, Reno School of Medicine, Nevada, Reno, USA ${ }^{4}$ Institute of Biomedical Science, Catholic Kwandong University International St. Mary's Hospital, Incheon, Korea

Correspondence to Professor Hee Man Kim; loverkorea2009@gmail.com and Professor Seok-Hoo Jeong; ssukoo@naver.com

\section{ABSTRACT}

Objectives To investigate an association between fatty liver disease (FLD) and erosive oesophagitis.

Design and setting This was a cross-sectional study of subjects selected from examinees who underwent health check-up, including oesophagogastroduodenoscopy in one hospital between 2004 and 2011. Erosive oesophagitis was classified according to the Los Angeles classification and FLD was diagnosed with ultrasonography. The anthropometric and laboratory data of the subjects were analysed using $\chi^{2}$ test and multivariate logistic regression. Additionally, we have analysed our data with two-stage least square estimation using the Baltagi-Chang one-way model to clarify unobserved confounding variable.

Primary outcome measure The effect of FLD on erosive oesophagitis.

Results Among the 14723 eligible subjects, 4232 (28.7\%) subjects diagnosed with FLD were classified into the fatty liver group and 10491 (71.3\%) subjects without FLD were classified into the non-fatty liver group. The incidence rate of erosive oesophagitis was significantly higher in the fatty liver group than in the non-fatty liver group (10.4\%vs6.1\%, $\mathrm{p}<0.0001)$. The multivariate analysis revealed that the fatty liver group was significantly associated with erosive oesophagitis (OR 1.19, 95\% Cl 1.03 to $1.37, \mathrm{p}=0.016)$. Conclusion FLD diagnosed by ultrasonography is an independent risk factor of erosive oesophagitis. It suggests that FLD-related metabolic abnormality may be associated with erosive oesophagitis.

\section{INTRODUCTION}

Gastro-oesophageal reflux disease (GERD) is a multifactorial disorder caused by a reflux of acidic gastric contents into the oesophagus, leading to tissue damage and symptoms. ${ }^{12}$ GERD is related to obesity and metabolic syndrome and has a negative effect on the quality of life and everyday activities from troublesome symptoms and complications. In the general population, the prevalence rate of GERD was approximately $30 \%$. $^{1-3}$

Fatty liver disease (FLD) includes alcoholic FLD and non-alcoholic FLD (NAFLD). NAFLD is defined as built-up fat exceeding $5 \%$ of hepatocytes without significant alcohol intake and any other causes of liver disease. ${ }^{45}$

\section{Strengths and limitations of this study}

- The sample size of 14723 is quite large to have statistical power to clarify the relationship between fatty liver disease (FLD) and erosive oesophagitis.

- This study showed that FLD was strongly associated with erosive oesophagitis.

- The limitation of this study was that alcohol intake of the subjects was evaluated precisely.

NAFLD ranges from simple steatosis and fatty liver in the early stage to non-alcoholic steatohepatitis, fibrosis and cirrhosis in the progressive stage. ${ }^{6}$ Recently, NAFLD has emerged as the principal cause of liver disease worldwide, because the prevalence rates of obesity, diabetes and dyslipidaemia, which easily contribute to NAFLD development, are increasing.

In Korea, increasingly westernised lifestyle and habits induce the increased prevalence rates of obesity, diabetes, dyslipidaemia, FLD as well as GERD. However, there were only few studies which investigated the relationship between GERD and FLD. ${ }^{7-9}$ Therefore, we investigated the association between erosive oesophagitis diagnosed by endoscopy and FLD diagnosed by ultrasonography in this study.

\section{METHODS}

\section{Study populations}

The study subjects were examinees who underwent health check-up in Myongji Hospital (Goyang city, Korea) between 2004 and 2011. The examination of the health check-up included questionnaires of medical history, laboratory tests, abdominal ultrasonography and oesophagogastroduodenoscopy. The subjects with age of $>18$ years were included. The exclusion criteria were as follows: (1) history of liver diseases, such as acute or chronic viral hepatitis, autoimmune 
liver disease, haemochromatosis and Wilson's disease, (2) liver cirrhosis of any causes and (3) history of past or current liver cancer. This study was approved.

\section{Methods}

This was designed as a cross-sectional study. All the subjects were divided into two groups: FLD group and non-FLD group, according to the presence or absence of FLD. The data were compared between two groups. The data for analysis were obtained from the medical records of the health check-up. The health questionnaire which all the subjects were requested to complete included data on sex, age, height, weight, social habits and medical history. The anthropometric and laboratory data included systolic blood pressure, diastolic blood pressure, fasting glucose level, serum lipid profile and liver function test.

Obesity was defined as a body mass index (BMI) of $\geq 25 \mathrm{~kg} / \mathrm{m}^{2}$. The criterion of high blood pressure was a systolic blood pressure $\geq 140 \mathrm{~mm} \mathrm{Hg}$ or diastolic blood pressure $\geq 90 \mathrm{~mm} \mathrm{Hg}$. A fasting blood glucose level $\geq 126 \mathrm{mg} / \mathrm{dL}$ was defined as a high fasting glucose. FLD was mainly diagnosed by abdominal ultrasonography. Erosive oesophagitis was classified using the Los Angeles classification system by oesophagogastroduodenoscopy. ${ }^{1011}$

\section{Patients and public involvement}

Patients and/or the general public were not involved in this study.

\section{Statistical analysis}

The SPSS V.18.0 software (IBM SPSS Statistics, IBM Corporation, Armonk, New York, USA) for MS Windows and STATA V.15.0 were used for the statistical analysis. Categorical variables were presented as absolute numbers or percentages and continuous data as means (SD). The two subgroups were compared using t-tests, and multivariable analyses for the risk factors of erosive oesophagitis were conducted. Additionally, we have analysed our data with two-stage least square estimation using the Baltagi-Chang one-way model (STATA V.15) to clarify unobserved confounding variable. Statistical analysis using two independent sample t-tests was performed. P values $<0.05$ were considered statistically significant.

\section{RESULTS}

The baseline characteristics of the 14723 subjects are shown in table 1 . Among the 14723 subjects, 4232 (28.7\%) patients were classified into the FLD group and 10491 $(71.3 \%)$ into the non-FLD group. The male proportion of the FLD group was higher than that of non-FLD group $(72.7 \%$ (3078) vs $45.4 \%$ (4766), $\mathrm{p}<0.0001)$. The mean age was higher in the FLD group than in the non-FLD group ( $50.1 \pm 12.2$ years vs $46.3 \pm 12.9$ years, $p<0.0001)$. The mean BMI was higher in the FLD group than in the non-FLD group $\left(25.9 \pm 2.8 \mathrm{~kg} / \mathrm{m}^{2}\right.$ vs $\left.23.0 \pm 2.9 \mathrm{~kg} / \mathrm{m}^{2}, \mathrm{p}<0.0001\right)$. The mean systolic blood pressure was higher in the FLD

\begin{tabular}{|c|c|c|c|}
\hline Variable & FLD group & $\begin{array}{l}\text { Non-FLD } \\
\text { group }\end{array}$ & $P$ values \\
\hline$n$ & 4232 & 10491 & \\
\hline Age (year) & $50.1 \pm 12.2$ & $46.3 \pm 12.9$ & $<0.0001$ \\
\hline Male sex & $3078(72.7 \%)$ & $4766(45.4 \%)$ & $<0.0001$ \\
\hline BMI $\left(\mathrm{kg} / \mathrm{m}^{2}\right)$ & $25.9 \pm 2.8$ & $23.0 \pm 2.9$ & $<0.0001$ \\
\hline $\mathrm{SBP}(\mathrm{mm} \mathrm{Hg})$ & $126.0 \pm 13.2$ & $119.3 \pm 14.2$ & $<0.0001$ \\
\hline $\mathrm{DBP}(\mathrm{mm} \mathrm{Hg})$ & $76.8 \pm 9.6$ & $71.8 \pm 10.4$ & $<0.0001$ \\
\hline $\begin{array}{l}\text { Fasting glucose (mg/ } \\
\mathrm{dL})\end{array}$ & $102.7 \pm 27.1$ & $92.3 \pm 17.3$ & $<0.0001$ \\
\hline Obesity (BMI) & & & $<0.0001$ \\
\hline$<18.5 \mathrm{~kg} / \mathrm{m}^{2}$ & $11(0.3 \%)$ & $460(4.4 \%)$ & \\
\hline 18.5 to $25 \mathrm{~kg} / \mathrm{m}^{2}$ & $1631(38.5 \%)$ & 7555 (72.0\%) & \\
\hline$\geq 25 \mathrm{~kg} / \mathrm{m}^{2}$ & $2590(61.2 \%)$ & $2476(23.6 \%)$ & \\
\hline High blood pressure & 857 (20.3\%) & $1133(10.8 \%)$ & $<0.0001$ \\
\hline High fasting glucose & $431(10.2 \%)$ & $285(2.7 \%)$ & $<0.0001$ \\
\hline Erosive oesophagitis & $440(10.4 \%)$ & $637(6.1 \%)$ & $<0.0001$ \\
\hline LA-A & $317(7.5 \%)$ & $480(4.6 \%)$ & \\
\hline LA-B & $115(2.7 \%)$ & $149(1.4 \%)$ & \\
\hline LA-C & $8(0.2 \%)$ & $5(0.05 \%)$ & \\
\hline LA-D & $0(0 \%)$ & $3(0.03 \%)$ & \\
\hline
\end{tabular}

High blood pressure: systolic blood pressure $\geq 140 \mathrm{~mm} \mathrm{Hg}$ or diastolic blood pressure $\geq 90 \mathrm{~mm} \mathrm{Hg}$.

High fasting glucose: $\geq 126 \mathrm{mg} / \mathrm{dL}$.

$\mathrm{BMI}$, body mass index; DBP, diastolic blood pressure; SBP, systolic blood pressure.

group than in the non-FLD group $(126.0 \pm 13.2 \mathrm{~mm} \mathrm{Hg}$ vs $119.3 \pm 14.2 \mathrm{~mm} \mathrm{Hg}, \mathrm{p}<0.0001)$. The mean diastolic blood pressure was higher in the FLD group than in the non-FLD group $(76.8 \pm 9.6 \mathrm{~mm} \mathrm{Hg}$ vs $71.8 \pm 10.4 \mathrm{~mm} \mathrm{Hg}, \mathrm{p}<0.0001)$. The mean fasting glucose level was higher in the FLD group than in the non-FLD group $(102.7 \pm 27.1 \mathrm{mg} / \mathrm{dL}$ vs $92.3 \pm 17.3 \mathrm{mg} / \mathrm{dL}, \mathrm{p}<0.0001)$. In the univariate analysis, $\mathrm{BMI} \geq 25 \mathrm{~kg} / \mathrm{m}^{2}$ (61.2\% vs $\left.23.6 \%, \mathrm{p}<0.0001\right)$, high blood pressure $(20.3 \%$ vs $10.8 \%, \mathrm{p}<0.0001)$ and high fasting glucose $(10.2 \%$ vs $2.7 \%, \mathrm{p}<0.0001)$ were significantly higher in the FLD group than in the non-FLD group. The prevalence rate of erosive oesophagitis was $7.3 \%$ (1077/14 723). The prevalence rate of erosive oesophagitis was higher in the FLD group than in non-FLD group ( $10.4 \%$ vs $6.1 \%, \mathrm{p}<0.001)$.

The multivariate analyses were performed to evaluate the association between erosive oesophagitis and FLD (table 2). FLD group (OR 1.19; 95\% CI 1.03 to 1.37 ; $\mathrm{p}=0.016$ ), male sex (OR 3.65; 95\% CI 3.11 to 4.29; $\mathrm{p}<0.0001$ ) and obesity (OR 2.02; 95\% CI 1.16 to 3.51 ; $\mathrm{p}=0.013$ ) have been identified as significant risk factors for erosive oesophagitis. However, high blood pressure (OR 1.04; $95 \%$ CI 0.88 to $1.24 ; \mathrm{p}=0.633$ ) and high fasting glucose (OR 1.20; $95 \%$ CI 0.94 to $1.54 ; \mathrm{p}=0.149$ ) were not statistically significant. 
Table 2 Multivariable analysis for the risk factors of erosive oesophagitis

\begin{tabular}{|c|c|c|}
\hline & $\begin{array}{l}\text { Erosive } \\
\text { oesophagitis }\end{array}$ & \\
\hline Variable & OR $(95 \% \mathrm{Cl})^{*}$ & $P$ values \\
\hline Fatty liver disease group & 1.19 (1.03 to 1.37$)$ & 0.016 \\
\hline Male sex & 3.65 (3.11 to 4.29$)$ & $<0.0001$ \\
\hline Obesity (BMI $\left.\geq 25 \mathrm{~kg} / \mathrm{m}^{2}\right)$ & $2.02(1.16$ to 3.51$)$ & 0.013 \\
\hline High blood pressure & $1.04(0.88$ to 1.24$)$ & 0.633 \\
\hline High fasting glucose & $1.20(0.94$ to 1.54$)$ & 0.149 \\
\hline
\end{tabular}

High blood pressure: systolic blood pressure $\geq 140 \mathrm{~mm}$ $\mathrm{Hg}$ or diastolic blood pressure $\geq 90 \mathrm{~mm} \mathrm{Hg}$; High fasting glucose: $\geq 126 \mathrm{mg} / \mathrm{dL}$.

${ }^{*}$ Age was adjusted.

$\mathrm{BMI}$, body mass index.

Additionally regression analyses using Baltagi-Chang one-way model were performed to investigate the risk factors of erosive oesophagitis (table 3). In both sexes, fatty liver (coefficient 0.0496 ; $95 \%$ CI -0.0050 to 0.1042 ; $\mathrm{p}=0.075$ ), considering the confounding role of obesity, was not identified as a significant risk factor of erosive oesophagitis. High blood pressure (coefficient -0.0426 ; $95 \%$ CI -0.0624 to $-0.0228 ; \mathrm{p}<0.0001$ ) showed a negative correlation and sex (male) (coefficient $0.0580 ; 95 \%$ CI 0.0433 to $0.0727 ; \mathrm{p}<0.0001$ ) showed a positive correlation with erosive oesophagitis. In men, fatty liver (coefficient $0.0876 ; 95 \%$ CI 0.0091 to $0.1661 ; \mathrm{p}=0.029$ ), considering

Table 3 Regression analysis using Baltagi-Chang for the risk factors of erosive oesophagitis

\begin{tabular}{|c|c|c|}
\hline \multirow[b]{2}{*}{ Variable } & Erosive oesophagitis & \multirow[b]{2}{*}{$P$ values } \\
\hline & Coefficient $(95 \% \mathrm{Cl})$ & \\
\hline \multicolumn{3}{|l|}{ In both sexes } \\
\hline $\begin{array}{l}\text { Fatty liver disease } \\
\text { group }\end{array}$ & $0.0496(-0.0050$ to 0.1042$)$ & 0.075 \\
\hline Gender & $0.0580(0.0433$ to 0.0727$)$ & $<0.0001$ \\
\hline High blood pressure & $-0.0426(-0.0624$ to 0.0228$)$ & $<0.0001$ \\
\hline High fasting glucose & $-0.0192(-0.0547$ to 0.0162$)$ & 0.287 \\
\hline \multicolumn{3}{|l|}{ In men } \\
\hline $\begin{array}{l}\text { Fatty liver disease } \\
\text { group }\end{array}$ & 0.0876 (0.0091 to 0.1661$)$ & 0.029 \\
\hline High blood pressure & $-0.0647(-0.0942$ to 0.0351$)$ & $<0.0001$ \\
\hline High fasting glucose & $-0.0046(-0.0524$ to 0.0432$)$ & 0.850 \\
\hline \multicolumn{3}{|l|}{ In women } \\
\hline $\begin{array}{l}\text { Fatty liver disease } \\
\text { group }\end{array}$ & $-0.0014(-0.0791$ to 0.0762$)$ & 0.970 \\
\hline High blood pressure & $-0.0143(-0.0411$ to 0.0124$)$ & 0.0293 \\
\hline High fasting glucose & $-0.0423(-0.0990$ to 0.0143$)$ & 0.143 \\
\hline
\end{tabular}

High blood pressure: systolic blood pressure $\geq 140 \mathrm{~mm}$ $\mathrm{Hg}$ or diastolic blood pressure $\geq 90 \mathrm{~mm} \mathrm{Hg}$; high fasting glucose: $\geq 126 \mathrm{mg} / \mathrm{dL}$. the confounding role of obesity, was identified as a significant risk factor of erosive oesophagitis. High blood pressure (coefficient $-0.0647 ; 95 \%$ CI -0.0942 to -0.0351 ; $\mathrm{p}<0.0001)$ showed a negative correlation with erosive oesophagitis. In women, fatty liver (coefficient -0.0014 ; $95 \%$ CI -0.0791 to $0.0762 ; \mathrm{p}=0.970$ ), considering the confounding role of obesity, was not identified as a significant risk factor of erosive oesophagitis.

\section{DISCUSSION}

Our study demonstrated that FLD group had higher prevalence of erosive oesophagitis, and FLD group was significantly associated with the increased risk of erosive oesophagitis.

GERD is a condition in which refluxed acidic gastric contents result in troublesome symptoms or complications. ${ }^{11}$ In Korea, the prevalence of GERD has increased gradually from $4.6 \%$ to $7.3 \% .^{12}$ In our study, the prevalence of erosive oesophagitis was $7.3 \%$. GERD is related to a variety of symptoms, such as heartburn (most common), regurgitation and difficulty of swallowing. ${ }^{13}$ Therefore, GERD has a negative effect on the quality of life and everyday activities of patients. GERD develops when the antireflux barrier comprising the lower oesophageal sphincter (LES) and the crucial portion of a hiatus do not function appropriately. LES function is associated with LES length (total and abdominal), intrinsic LES pressure (LESP) and duration and frequency of transient LES relaxation. ${ }^{14}$ LES function is attenuated by several factors, such as an increased BMI, intra-abdominal pressure, intragastric pressure, inspiratory intrathoracic pressure and hiatal hernia. High-fat diet and caloric intake increase weight and obesity, which reduce the intrinsic LESP and increase the frequency of transient LES relaxation; these consequently lead to GERD. ${ }^{15} 16$ Therefore, obesity is a risk factor of GERD. In addition, patients with GERD have overexpressed cytokines in the mucosa of the oesophagus. Obesity triggers oesophageal mucosal injury because a variety of cytokines are produced by adipose tissues and macrophages. ${ }^{1718}$

The prevalence of FLD ranges from $25 \%$ to $45 \%$ worldwide. FLD includes alcoholic FLD and NAFLD. The pathophysiology of NAFLD involves multifactorial mechanisms affected by environmental, genetic and metabolic factors. ${ }^{19}$ Visceral adipose tissues alter the metabolism of lipid and glucose. As a result, hepatocyte fat accumulates, inflammatory milieu injures the liver and other tissues generate. Lipid toxicity, apoptotic process, oxidative stress and endoplasmic reticular stress lead to liver damage and progressive fibrosis. ${ }^{20}$ Increased BMI and obesity are documented risk factors of NAFLD. ${ }^{19}$

From previous studies, we have known that obesity was a risk factor of GERD and NAFLD. In this regard, the present study investigated whether FLD is a risk factor of GERD. In addition, a recent study reported that NAFLD was strongly associated with GERD. ${ }^{9}$ However, this study has some limitations, including its small sample size; 
further, only patients with gastrointestinal problems were included, not the general population. Conversely, the present study included numerous subjects for health check-up examination and reported that obesity $\left(\right.$ BMI $\left.\geq 25 \mathrm{~kg} / \mathrm{m}^{2}\right)$, high blood pressure, high fasting glucose and erosive oesophagitis were significantly higher in the FLD group than in the non-FLD group. In the multivariate analysis, the risk factors of erosive oesophagitis were FLD group, male sex and obesity. Therefore, our study suggests that FLD is a risk factor of GERD which is consistent with those of previous studies.

There were some advantages in the present study. First, we included all subjects for health check-up examination. Second, this study has the largest sample size among studies in the literature to date. In this regard, this study may be more useful in the clinical practice. However, it is limited by its retrospective design, and we did not survey alcohol intake precisely. Future prospective studies are needed to elucidate the mechanism for the associations between FLD and erosive oesophagitis.

In conclusion, the present study reports that FLD is an independent risk factor of erosive oesophagitis in Korean population. The mechanism and pathophysiology between fatty liver and erosive oesophagitis should be further evaluated in future studies.

Contributors JSC, S-HJ and HMK were involved in study conception and design; $\mathrm{KJH}, \mathrm{SL}$ and Y-JY conducted statistical analyses; all authors were involved in the drafting and critical revision of the manuscript, and approved the final version, including the authorship list.

Funding The authors have not declared a specific grant for this research from any funding agency in the public, commercial or not-for-profit sectors.

Competing interests None declared.

Patient consent Not required.

Ethics approval This study was approved by the Institutional Review Board of Myongji Hospital (IRB N0. 11-093).

Provenance and peer review Not commissioned; externally peer reviewed.

Data sharing statement Data are not available.

Open access This is an open access article distributed in accordance with the Creative Commons Attribution Non Commercial (CC BY-NC 4.0) license, which permits others to distribute, remix, adapt, build upon this work non-commercially, and license their derivative works on different terms, provided the original work is properly cited, appropriate credit is given, any changes made indicated, and the use is non-commercial. See: http://creativecommons.org/licenses/by-nc/4.0/.

\section{REFERENCES}

1. Ronkainen J, Agréus L. Epidemiology of reflux symptoms and GORD. Best Pract Res Clin Gastroenterol 2013;27:325-37.

2. El-Serag HB, Sweet S, Winchester CC, et al. Update on the epidemiology of gastro-oesophageal reflux disease: a systematic review. Gut 2014;63:871-80.

3. Camilleri M, Dubois D, Coulie B, et al. Prevalence and socioeconomic impact of upper gastrointestinal disorders in the United States: results of the US Upper Gastrointestinal Study. Clin Gastroenterol Hepatol 2005;3:543-52.

4. Tarantino G, Saldalamacchia G, Conca P, et al. Non-alcoholic fatty liver disease: further expression of the metabolic syndrome. $J$ Gastroenterol Hepatol 2007;22:293-303.

5. Blachier M, Leleu H, Peck-Radosavljevic M, et al. The burden of liver disease in Europe: a review of available epidemiological data. $J$ Hepatol 2013;58:593-608.

6. Angulo P. Nonalcoholic fatty liver disease. $N$ Engl J Med 2002;346:1221-31.

7. Fujikawa $\mathrm{Y}$, Tominaga $\mathrm{K}$, Fujii $\mathrm{H}$, et al. High prevalence of gastroesophageal reflux symptoms in patients with non-alcoholic fatty liver disease associated with serum levels of triglyceride and cholesterol but not simple visceral obesity. Digestion 2012;86:228-37.

8. Miele L, Cammarota G, Vero V, et al. Non-alcoholic fatty liver disease is associated with high prevalence of gastro-oesophageal reflux symptoms. Dig Liver Dis 2012;44:1032-6.

9. Catanzaro R, Calabrese F, Occhipinti S, et al. Nonalcoholic fatty liver disease increases risk for gastroesophageal reflux symptoms. Dig Dis Sci 2014;59:1939-45.

10. Dent J, Brun J, Fendrick AM, et al. An evidence-based appraisal of reflux disease management--the Genval Workshop Report. Gut 1999;44(Suppl 2):S1-16.

11. Vakil N, van Zanten SV, Kahrilas P, et al. The Montreal definition and classification of gastroesophageal reflux disease: a global evidencebased consensus. Am J Gastroenterol 2006;101:1900-20. quiz 43.

12. Kim KM, Cho YK, Bae SJ, et al. Prevalence of gastroesophageal reflux disease in Korea and associated health-care utilization: a national population-based study. J Gastroenterol Hepatol 2012;27:741-5.

13. Patrick L. Gastroesophageal reflux disease (GERD): a review of conventional and alternative treatments. Altern Med Rev 2011;16:116-33.

14. Prachand VN, Alverdy JC. Gastroesophageal reflux disease and severe obesity: fundoplication or bariatric surgery? World $J$ Gastroenterol 2010;16:3757-61

15. Hajar N, Castell DO, Ghomrawi H, et al. Impedance $\mathrm{pH}$ confirms the relationship between GERD and BMI. Dig Dis Sci 2012;57:1875-9.

16. Jung HS, Choi MG, Baeg MK, et al. Obesity is associated with increasing esophageal Acid exposure in korean patients with gastroesophageal reflux disease symptoms. J Neurogastroenterol Motil 2013;19:338-43.

17. Haase J, Weyer $\mathrm{U}$, Immig K, et al. Local proliferation of macrophages in adipose tissue during obesity-induced inflammation. Diabetologia 2014;57:562-71.

18. McGown C, Birerdinc A, Younossi ZM. Adipose tissue as an endocrine organ. Clin Liver Dis 2014;18:41-58.

19. Singal AG, Manjunath $H$, Yopp AC, et al. The effect of PNPLA3 on fibrosis progression and development of hepatocellular carcinoma: a meta-analysis. Am J Gastroenterol 2014;109:325-34.

20. Rinella ME. Nonalcoholic fatty liver disease: a systematic review. JAMA 2015;313:2263-73. 